\title{
Determining Bone Turnover Status in Patients With Chronic Liver Disease
}

\author{
Tayyaba Bukhari ${ }^{1}$, Lena Jafri ${ }^{1}$, Hafsa Majid ${ }^{1}$, Aysha Habib H. Khan ${ }^{1}$, Imran Siddiqui ${ }^{1}$ \\ 1. Pathology \& Laboratory Medicine, Aga Khan University Hospital, Karachi, PAK
}

Corresponding author: Imran Siddiqui, imran.siddiqui@aku.edu

\begin{abstract}
Introduction

Hepatic osteodystrophy is an osteoporotic bone disease that occurs in chronic liver disease patients. The global prevalence of osteoporosis in patients with chronic liver disease is 30\% to $40 \%$. The pathogenesis of hepatic bone disease is not clear, but it occurs due to unstable bone remodeling with increased bone resorption and decreases bone formation. There has been an interest in determining the clinical utility of bone turnover markers (BTMs) in the assessment of osteoporosis in chronic liver patients.
\end{abstract}

\section{Methods}

This was a cross-sectional study conducted in patients with chronic liver disease at the section of chemical pathology, department of pathology and laboratory medicine, Aga Khan University (AKU). A total of 50 patients with age $>8$ years and a history of liver disease $>6$ months were recruited from January to October 2019. Liver function tests, i.e. aspartate aminotransferase (AST), alanine transaminase (ALT), albumin, and bilirubin, along with clinical signs of liver disease chronicity, were noted. The samples for BTMs, i.e. total serum alkaline phosphatase (ALP) and serum C-terminal telopeptide of type-1 collagen (CTX) were withdrawn and analyzed on Microlab (ELItech Group, Puteaux, France) and ADVIA Centaur (Siemens Diagnostics, NY), respectively.

\section{Results}

The majority of patients were males ( $\mathrm{n}=34,68 \%$ ). Twenty-four (48\%) patients suffered from fibrosis while 26 (52\%) were without fibrosis. Median platelet count $\left(68 \times 10^{9} / \mathrm{L}(102.5-50)\right)$ and median cholesterol levels $(102.5 \mathrm{mg} / \mathrm{dl}$ (147-99.5)) were decreased, whereas gamma-glutamyl transferase (GGT) levels were higher in the fibrosis group as compared to the non-fibrosis group. The median levels of total ALP were 91.5 IU/L (10382), and the median levels of CTX were $0.24 \mathrm{pg} / \mathrm{ml}(0.34-0.21)$.

\section{Conclusion}

In the present study, no significant difference was found in the BTMs of patients with and without chronic liver disease (CLD). However, there was a positive and significant correlation of BTMs, particularly CTX with

Review began 10/06/2020 Review ended 11/17/2020 Published 04/13/2021

\section{๑) Copyright 2021}

Bukhari et al. This is an open access article distributed under the terms of the Creative Commons Attribution License CC-BY 4.0., which permits unrestricted use, distribution, and reproduction in any medium, provided the original author and source are credited. age, bilirubin levels, and hepatomegaly.

Categories: Internal Medicine, Pathology, Gastroenterology

Keywords: osteodystrophy, fibrosis, bone resorption, bone remodeling

\section{Introduction}

Osteoporosis is the most common bone disorder in patients suffering from chronic liver disease (CLD) and is often known as hepatic osteodystrophy. Osteoporosis is an asymptomatic condition with decreased bone mass, altered bone structure, and low bone strength, which may result in frequent fractures and leads to significant morbidity in this population [1-2]. A literature review on osteoporosis in the Pakistani population by AH Khan et al. showed that the prevalence of osteoporosis range from $5.6 \%$ to $17.8 \%$ in premenopausal females and $20 \%-49.3 \%$ in postmenopausal females amongst the Pakistani population [3]. CLD is considered a secondary cause of osteoporosis [4-5], as the liver plays a major role in the production of various growth factors and hormones governing many metabolic activities affecting bone. However, the burden of osteoporosis in patients suffering from CLD is not investigated in our population.

Chronic liver disease is one of the most common diseases with a worldwide increase in prevalence and a high risk of irreversible tissue damage leading to cirrhosis. There are multiple etiologies like alcoholism, chronic viral disease, excess tissue iron deposition, immunosuppressive therapy following liver transplantation, etc. [6]. The prevalence of osteoporosis in patients with CLD is 30\% to $40 \%$ worldwide [7-9]. The pathogenesis of a hepatic bone disease is multifaceted, complex, and difficult to understand but if narrated in simple words, it occurs due to unstable bone remodeling with increased bone resorption and decreased bone formation [10-13]. 
Liver cirrhosis is associated with high mortality and morbidity. Particularly in developing countries like Pakistan, the rate of progression of viral hepatitis to liver cirrhosis is high, with nearly $41 \%-52 \%$ cases of hepatitis $\mathrm{C}$ virus and 30\% with hepatitis B virus cases progressing to develop cirrhosis [14]. With therapeutic improvement, the survival of CLD patients has increased, but so has the risk of extra-hepatic manifestations such as osteoporosis. The literature on the status of bone turnover in CLD patients of our population is scarce. The potential socioeconomic burden of developing osteoporosis with increased fracture risk in CLD patients, in a country like Pakistan with a paucity of available health resources, is an enormous challenge and needs increased awareness and early treatment. The current study aimed to determine the association and correlation of bone turnover markers (BTMs) with biochemical markers in CLD patients.

\section{Materials And Methods}

It was a cross-sectional study conducted from January to October 2019 in known patients with chronic viral hepatitis, registered at the gastroenterology clinic of Aga Khan University Hospital. Permission from the ethical review committee of Aga Khan University Karachi, Pakistan (ERC \# PAT-5105) was taken before the initiation of the study. Only adults (18-65 years of age) with a history of viral hepatitis for more than six months of duration were recruited. While patients with CLD due to any other cause other than viral hepatitis were excluded.

Patients were recruited from the gastroenterology clinic, coming for a fibroscan analysis. Detailed clinical history after informed consent was obtained on a structured questionnaire. Physical examination of patients was performed to note the presence or absence of jaundice, hepatomegaly, ascites, and encephalopathy. Eight to 10 milliliters of the non-fasting blood sample was drawn in serum separator tubes for biochemical analysis of aspartate aminotransferase (AST), alanine transaminase (ALT), gamma-glutamyl transferase (GGT), cholesterol, albumin, total bilirubin, total alkaline phosphatase (ALP) and C-terminal telopeptide of type-1 collagen (CTX). Serum total ALP was analyzed on Microlab 300 (ELItech Group, Puteaux, France) using reagents by Merck \& Co. ( Kenilworth, NJ) while serum CTX estimation was done on ADVIA Centaur analyzer (Siemens Diagnostics, NY). All the rest of the biochemical analysis was done on ADVIA 1800 (Siemens Diagnostics). All samples were analyzed in batches with three levels of quality control material run in each batch to validate the results. Patients were also assessed by the Fibroscan analyzer ((Echosens, Paris, France) to determine the extent of fibrosis in the liver. A cutoff of 7.2 was used to identify fibrosis using Fibroscan [15].

\section{Statistical analysis}

Data were analyzed in the Statistical Package of the Social Services (SPSS) version 21 (Copyright 1985-2015; IBM Corp., Armonk, NY). The Shapiro-Wilk test was applied to check the hypothesis of normality for quantitative (continuous) variables. Values are supposed to be offered as mean \pm standard deviation or median with interquartile range (IQR) for unceasing variables. Qualitative variables were presented by using frequency and percentages. The Mann-Whitney U test was applied to compare the median difference of AST, ALT, albumin, total bilirubin, ALP, and CTX in fibrosis versus non-fibrosis patients. Post-stratification Spearman's coefficients of correlation test applied to compare the association between both groups. The bone turnover markers were compared with the degree of fibrosis assessed by Fibroscan.

\section{Results}

A total of 50 patients with a history of CLD for more than six months were included in this study, out of which the majority were males $(n=34,68 \%)$, and $32 \%(n=16)$ were females. Forty-eight percent $(n=24)$ of patients were $>40$ years of age. The demographics and clinical and biochemical characteristics of patients are further described in Table 1 . 


\section{Cureus}

\begin{tabular}{|c|c|}
\hline Demographics Characteristics & n (\%) \\
\hline Male & $34(68 \%)$ \\
\hline Age $<40$ years & $26(52 \%)$ \\
\hline Fibrosis on fibroscan & $24(48 \%)$ \\
\hline Jaundice & $2(4 \%)$ \\
\hline Ascites & $3(6 \%)$ \\
\hline Hepatomegaly & $1(2 \%)$ \\
\hline Anti HCV positive & $35(70 \%)$ \\
\hline HBsAg positive & $15(30 \%)$ \\
\hline Elevated serum ALT (Reference range <45 IU/L)) & $38(76 \%)$ \\
\hline Elevated serum AST (Reference range<35IU/L) & $37(74 \%)$ \\
\hline Elevated serum GGT (Reference range <55IU/L) & $21(42 \%)$ \\
\hline Elevated serum total bilirubin $(0.1-1.2 \mathrm{mg} / \mathrm{dl})$ & $6(12 \%)$ \\
\hline Elevated serum direct bilirubin (0.0-0.3 mg/dl) & $16(32 \%)$ \\
\hline Elevated serum ALP (Reference range 45-129lU/L) & --- \\
\hline Elevated serum CTX (Reference 16-934 pg/ml) & $2(4 \%)$ \\
\hline
\end{tabular}

TABLE 1: Frequency distribution of clinical and biochemical characteristics of study subjects with chronic hepatitis $(n=50)$

HCV: hepatitis C virus; ALT: alanine transaminase; AST: aspartate aminotransferase; GGT: gamma-glutamyl transferase; ALP: total alkaline phosphatase; CTX: C-terminal telopeptide

There was an almost equal distribution of patients with fibrosis $(n=24,48 \%)$ and without fibrosis $(n=26$, $52 \%)$. The majority of the subjects had elevated liver enzymes. However, total ALP and CTX were within the reference range in all subjects. Table 2 shows the comparison between groups with fibrosis and non-fibrosis. 


\section{Cureus}

\begin{tabular}{|c|c|c|c|c|}
\hline Study Variables & Overall $(n=50)$ & Patients with fibrosis $(n=24)$ & Patients without fibrosis $(n=26)$ & p-value \\
\hline Median age in years & $40(50-30)$ & $43(52.5-34.5)$ & $38(46-29)$ & 0.085 \\
\hline Median serum bilirubin total(mg/dll) & $0.6(0.9-0.4)$ & $0.6(0.95-0.4)$ & $0.6(0.8-0.4)$ & 0.747 \\
\hline Median serum albumin(g/dl) & $3.6(4-3)$ & $3.65(4.25-3)$ & 3.55(4-3.2) & 0.953 \\
\hline Median serum ALT(IU/L) & 48(84-34) & $56(89-42)$ & $42.5(54-25)$ & $0.045^{*}$ \\
\hline Median serum AST(IU/L) & 39.5(49-30) & $44(54.5-34)$ & $36(45-25)$ & 0.091 \\
\hline Median serum GGT(U/L) & $30(68-15)$ & $50(86-14.5)$ & $26.5(56-15)$ & 0.303 \\
\hline Median serum Cholesterol(mg/dl) & $142(169-100)$ & $102.5(147-99.5)$ & $152(188-110)$ & $0.006^{\star}$ \\
\hline Median platelet count (no./mm3) & $118.5(250-70)$ & 68(102.5-50) & $237.5(306-130)$ & $<0.001^{\star}$ \\
\hline Median serum total ALP (IU/L) & 91.5(103-82) & $95(102-86)$ & 85.5(103-75) & 0.248 \\
\hline Median serum CTX (pg/ml) & $240(340-210)$ & $230(280-200)$ & $280(490-210)$ & 0.134 \\
\hline
\end{tabular}

TABLE 2: Comparison of median levels of biochemical markers in liver disease and bone turnover in patients with and without liver fibrosis

The Mann-Whitney U-test was applied, at a $95 \%$ confidence interval with a $5 \%$ level of significance; ${ }^{*} p$-value is statistically significant.

ALT: alanine transaminase; AST: aspartate aminotransferase; GGT: gamma-glutamyl transferase; ALP: total alkaline phosphatase; CTX: C-terminal telopeptide

The median comparison showed platelet count, serum cholesterol, and serum ALT levels to be statistically significant between the two groups. Median platelet count $68 \times 109 / \mathrm{L}(102.5-50)$ and median cholesterol levels $102.5 \mathrm{mg} / \mathrm{dl}$ (147-99.5) were decreased, whereas GGT levels were higher in patients with fibrosis. Median levels of total ALP were 91.5 IU/L (103-82) and median levels of CTX were $240 \mathrm{pg} / \mathrm{ml}$ (340-210), and the difference was statistically non-significant (Table 2). Table 3 describes the association of biochemical markers with each other. 


\begin{tabular}{|c|c|c|c|c|c|c|c|c|c|c|}
\hline & Cholesterol & GGT & Platelet Count & Fibroscan & ALT & AST & Total Bilirubin & Albumin & ALP & CTX \\
\hline Cholesterol & 1.000 & -.066 & $.418^{\star \star}$ & $-.501^{\star \star}$ & -.008 & .095 & .055 & -.158 & .193 & .161 \\
\hline GGT & -.066 & 1.000 & 109 & .173 & .227 & .139 & .176 & -.146 & .038 & -.268 \\
\hline Platelet count & $.418^{\star \star}$ & 109 & 1.000 & $-.820^{\star \star}$ & -.184 & -.084 & .080 & -.154 & -.017 & .104 \\
\hline Fibroscan & $-.501^{\star \star}$ & .173 & $-.820^{\star \star}$ & 1.000 & .179 & .023 & -.032 & .194 & -.045 & -.182 \\
\hline ALT & -.008 & .227 & -.184 & 179 & 1.000 & $.565^{\star \star}$ & $.303^{\star}$ & -.264 & .030 & $-.368^{\star *}$ \\
\hline AST & .095 & 139 & .084 & .023 & $.565^{\star \star}$ & 1.000 & $.437^{\star \star}$ & $-.318^{\star}$ & .020 & -.243 \\
\hline Bilirubin total & .055 & .176 & .080 & -.032 & $.303^{*}$ & $.437^{\star \star}$ & 1.000 & $-.407^{\star \star}$ & -.067 & $-.335^{\star}$ \\
\hline Albumin & -.158 & -.146 & -.154 & .194 & -.264 & $-.318^{\star}$ & $-.407^{\star \star}$ & 1.000 & -.267 & .086 \\
\hline Alk phosphatase & .193 & .038 & -.017 & -.045 & .030 & .020 & -.067 & -.267 & 1.000 & .082 \\
\hline CTX (ng/ml) & .161 & -.268 & .104 & -.182 & $-.368^{\star \star}$ & -.243 & $-.335^{\star}$ & .086 & .082 & 1.000 \\
\hline
\end{tabular}

\section{TABLE 3: Spearman's coefficients of correlation among CTX, alkaline phosphatase, Fibroscan,} and liver function markers

Correlation is significant at the 0.01 level $(2 \text {-tailed })^{\star *}$

Correlation is significant at the 0.05 level (2-tailed)*

GGT: gamma-glutamyl transferase; ALT: alanine transaminase; AST: aspartate aminotransferase; ALP: total alkaline phosphatase; CTX: C-terminal telopeptide

Liver enzymes, AST and ALT, showed a positive association with each other (r-value 0.56, p-value $<0.01)$. Poor correlation was noted between CTX and other biochemical markers. However, serum CTX showed a weak inverse association that was statistically significant with ALT (r-value -0.36 , p-value $<0.01$ ) and total bilirubin (r-value -0.33 , p-value $<0.05$ ).

\section{Discussion}

Literature reports that hepatitis B and C are associated with significantly reduced bone density measurements even in the absence of cirrhotic changes. Viral hepatitis usually presents with increased immune response and release of many resorption-activating cytokines, increasing the duration of liver disease and deteriorating function, further enhancing bone resorption and hence increasing bone loss. Treatment of viral hepatitis with interferon increases the complexity of understanding the cause of bone loss in liver disease [16]. The pathogenesis of hepatic bone disease in patients with CLD is not exactly known; there are multiple factors involved like deficiency of vitamin D and insulin-like growth factor (IGF-1) [17-18], hyperbilirubinemia, and hypogonadism (estrogen and testosterone deficiency), which contribute to bone loss in chronic liver disease.

Findings from the current study show that bone turnover markers (ALP and CTX) were within the reference range in all the studied subjects suffering from chronic hepatitis. Even patients with fibrosis (diagnosed using a Fibroscan cutoff of 7.2) showed values within the reference range. The results of this study also depict that BTMs are not associated with the progression of liver disease or disease severity. CTX and Fibroscan values showed a weak association ( $\mathrm{r}-0.18$, $\mathrm{p}$-value $>0.05)$.

Table 4 shows a comparison with other studies in which bone turnover was assessed in liver fibrosis patients. In contrast to our study that shows no increase in bone turnover with normal total ALP and serum CTX levels, bone turnover was found to be increased in all previous studies conducted by Guanabens, Corazza G, George J, and Goral V et al. [19-22]. Normal CTX levels seem to have an association with our population/ethnicity, as in another study conducted by ST Naeem et al., serum CTX levels were found to be normal in postmenopausal Pakistani women with decreased bone mineral density (BMD) on dual-energy Xray absorptiometry (DXA) scan [23]. The reason for the normal to a very mild increase in CTX in our population needs further investigation and CTX cannot be utilized to predict the development of liver osteodystrophy in the Pakistani population. 


\section{Cureus}

\begin{tabular}{|c|c|c|c|c|c|}
\hline Country & Authors & Year & Study subjects & $\begin{array}{l}\text { Sample } \\
\text { size, } n\end{array}$ & Bone markers studied and study findings \\
\hline Italy & $\begin{array}{l}\text { A.Mantovani } \\
\text { et al }\end{array}$ & 2019 & $\begin{array}{l}\text { Post-menopausal women } \\
\text { with diabetes with NAFLD } \\
\text { in } 3 \text { groups: No-NAFLD, } \\
\text { patients with NAFLD and } \\
\text { fibrosis, patients with } \\
\text { NAFLD with no fibrosis }\end{array}$ & 77 & $\begin{array}{l}\text { Bone formation inhibitors: NAFLD and fibrosis showed increased } \\
\text { sclerostin levels ( } 54.1 \pm 16.4 \text { vs. } 36.1 \pm 11.9 \text { vs. } 42.3 \pm 14.7 \text { pmol/L) and } \\
\text { decreased serum DKK- } 1(26.6 \pm 17.8 \text { vs. } 49.0 \pm 22.4 \text { vs. } 2.9 \pm 19.4 \\
\text { pmol/L). Resorption markers: NAFLD and fibrosis group had decreased } \\
\text { sCTX }(0.16 \pm 0.09 \text { vs. } 0.29 \pm 0.17 \text { vs. } 0.40 \pm 0.28 \mathrm{ng} / \mathrm{mL} \text { ) and increased } \\
\text { RANKL ( } 0.04 \pm 0.03 \text { vs. } 0.08 \pm 0.06 \text { vs. } 0.11 \pm 0.06 \text { pmol/L) compared to } \\
\text { other groups. }\end{array}$ \\
\hline Turkey & Goral $\mathrm{V}$ et al & 2010 & $\begin{array}{l}\text { Liver cirrhosis due to viral } \\
\text { hepatitis and primary } \\
\text { biliary cirrhosis }\end{array}$ & 85 & $\begin{array}{l}\text { Formation markers: Increased ALP } 109.2 \pm 57 \text { IU/L, Decreased } \\
\text { osteocalcin } 1.05 \pm 2.5 \mathrm{ng} / \mathrm{ml} \text {, Resorption markers: Normal UDPD to } \\
\text { creatinine ratio } 9.4 \pm 9.9\end{array}$ \\
\hline India & $\begin{array}{l}\text { George J et } \\
\text { al. }\end{array}$ & 2009 & $\begin{array}{l}\text { Viral and alcoholic } \\
\text { hepatitis leading to liver } \\
\text { cirrhosis }\end{array}$ & 72 & $\begin{array}{l}\text { Formation markers: Normal ALP } 138 \pm 61(132.7) \text { IU\&/L, Decreased } \\
\text { osteocalcin } 2.99 \pm 2.5(1.8) \mathrm{ng} / \mathrm{ml} \text {, Resorption markers: Increased UDPD } \\
\text { to creatinine ratio } 11.5 \pm 4.5(12.1)\end{array}$ \\
\hline Italy & $\begin{array}{l}\text { Corazza G } \\
\text { et al. }\end{array}$ & 2000 & $\begin{array}{l}\text { Viral hepatitis leading to } \\
\text { liver cirrhosis }\end{array}$ & 68 & $\begin{array}{l}\text { Formation markers: Normal PICP }(132 \pm 36) \mathrm{ng} / \mathrm{ml} \text {, increased osteocalcin } \\
11 \pm 7 \mathrm{ng} / \mathrm{ml} \text {, Resorption marker: Increased ICTP }(6.6 \pm 4.2) \mathrm{ng} / \mathrm{ml}\end{array}$ \\
\hline Spain & $\begin{array}{l}\text { Guanabens } \\
\text { et al. }\end{array}$ & 1998 & $\begin{array}{l}\text { Liver fibrosis due to } \\
\text { primary biliary cirrhosis }\end{array}$ & 34 & $\begin{array}{l}\text { Formation markers: Decreased osteocalcin }(16.4 \pm 1.2) \mathrm{ng} / \mathrm{ml} \text {, increased } \\
\text { PICP }(122.2 \pm 5.9) \text { and increased PINP }(40.7 \pm 5.3) \mathrm{ng} / \mathrm{ml} \text {, Resorption } \\
\text { markers: Increased PYR }(65.3 \pm 4.4) \mathrm{nM} / \mathrm{mM} \text {, increased DPYR }(9.9 \pm 1.1) \\
\mathrm{nM} / \mathrm{mM} \text {, increased HYP }(86.1 \pm 6.9) \mathrm{nM} / \mathrm{mg} \text {, increased NTX }(68.9 \pm 9.3) \\
\text { nMBCE } / \mathrm{mM} \text {, and increased CTX }(213.5 \pm 28.3) \mathrm{ug} / \mathrm{mm}\end{array}$ \\
\hline
\end{tabular}

\section{TABLE 4: Comparison with other studies regarding bone turnover status in chronic liver disease}

NAFLD: non-alcoholic fatty liver disease; DKK-1: Dickkopf-related protein-1; RANKL: receptor activator of nuclear factor к $\beta$ ligand; PICP: carboxyterminal propeptide of type I procollagen; PINP: amino-terminal propeptide of type I procollagen; ALP: total alkaline phosphatase; ICTP: telopeptide of type I collagen; TRAP: tartrate-resistant acid phosphatase; HYP: hydroxyproline; PYR: pyridinoline; DPYR: deoxypyridinoline; NTX: type I collagen cross-linked N; CTX: C-telopeptide; UDPD: urinary deoxypyridinoline

There are certain limitations to the study. First, the sample size of the study was small, and another study with a larger sample size in both groups (with and without fibrosis) is further needed. The current study was not longitudinal and bone mineral density using DXA scans was not measured. The serum measurements were taken at a single point thus could miss the associations between inflammatory markers, BTMs, i.e. ALP, CTX, and Fibroscan findings, as the increased inflammatory response to viral infection can contribute to more bone loss. The information about the stage of liver cirrhosis was not available. Additionally, more BTM can be added in future studies to understand the clinical utility of these BTM in chronic hepatitis patients who are at risk of hepatic osteodystrophy.

\section{Conclusions}

In the present study, no significant difference was found in the BTMs of patients with and without CLD. However, there was a positive and significant correlation of BTMs, particularly CTX, with age, bilirubin levels, and hepatomegaly. In conclusion, bone loss in liver disease is still under question, and the role of BTMs for assessing early bone loss in liver disease is uncertain and needs further investigation. The role of systematic inflammation and its association with hepatic osteodystrophy should be considered and investigated.

\section{Additional Information}

\section{Disclosures}

Human subjects: Consent was obtained or waived by all participants in this study. Ethical Review committee of Aga Khan University Hospital issued approval PAT-5105. the Approval was given by the ERC committee of Aga Khan University, Karachi, Pakistan. Animal subjects: All authors have confirmed that this study did not involve animal subjects or tissue. Conflicts of interest: In compliance with the ICMJE uniform disclosure form, all authors declare the following: Payment/services info: All authors have declared that no financial support was received from any organization for the submitted work. Financial relationships: All authors have declared that they have no financial relationships at present or within the previous three years with any organizations that might have an interest in the submitted work. Other relationships: All authors have declared that there are no other relationships or activities that could appear to have influenced the submitted work. 


\section{References}

1. Sözen T, Özışık L, Başaran NC: An overview and management of osteoporosis . Eur J Rheumatol. 2017, 4:4656. 10.5152/eurjrheum.2016.048

2. NIH Consensus Development Panel on Osteoporosis Prevention, Diagnosis, and Therapy: Osteoporosis prevention, diagnosis, and therapy. JAMA. 2001, 285:785-795. 10.1001/jama.285.6.785

3. Khan AH, Jafri L, Ahmed S, Noordin S: Osteoporosis and its perspective in Pakistan: a review of evidence and issues for addressing fragility fractures. Ann Med Surg. 2018, 29:19-25. 10.1016/j.amsu.2018.03.019

4. Muldowney FP, Neale G: Generalised disorders of bone associated with disease of the gastro-intestinal tract. Ir J Med Sci. 1974, 143:57. 10.1007/BF02938127

5. Nakchbandi IA: Osteoporosis and fractures in liver disease: relevance, pathogenesis and therapeutic implications. World J Gastroenterol. 2014, 20:9427-9438.

6. Handzlik-Orlik G, Holecki M, Wilczyński K, Duława J: Osteoporosis in liver disease: pathogenesis and management. Ther Adv Endocrinol Metab. 2016, 7:128-135. 10.1177/2042018816641351

7. Matloff DS, Kaplan MM, Neer RM, Goldberg MJ, Bitman W, Wolfe HJ: Osteoporosis in primary biliary cirrhosis: effects of 25-hydroxyvitamin D3 treatment. Gastroenterology. 1982, 83:97-102. 10.1016/S00165085(82)80291-6

8. Cuthbert JA, Pak CYC, Zerwekh JE, Glass KD, Combes B: Bone disease in primary biliary cirrhosis: increased bone resorption and turnover in the absence of osteoporosis or osteomalacia. Hepatology. 1984, 4:1-8. 10.1002/hep.1840040101

9. Stellon AJ, Webb A, Compston JE: Bone histomorphometry and structure in corticosteroid-treated chronic active hepatitis. Gut. 1988, 29:378-384. 10.1136/gut.29.3.378

10. Gatta A, Verardo A, Di Pascoli M, Giannini S, Bolognesi M: Hepatic osteodystrophy. Clin Cases Miner Bone Metab. 2014, 11:185.

11. Crosbie OM, Freaney R, McKenna MJ, Hegarty JE: Bone density, vitamin D status, and disordered bone remodeling in end-stage chronic liver disease. Calcified tissue international. 1999, 64:295-300. 10.1007/s002239900622

12. Collier JD, Ninkovic M, Compston JE: Guidelines on the management of osteoporosis associated with chronic liver disease. Gut. 2002, 50:i1-i9. 10.1136/gut.50.suppl_1.i

13. Gallego-Rojo FJ, Gonzalez-Calvin JL, Muñoz-Torres M, Mundi JL, Fernandez-Perez R, Rodrigo-Moreno D: Bone mineral density, serum insulin-like growth factor I, and bone turnover markers in viral cirrhosis . Hepatology. 1998, 28:695-699. 10.1002/hep.510280315

14. Memon MS, Zaki M: Burden of chronic liver disease and liver transplantation in Sindh . JLUMHS. 2013, 12:01.

15. Parikh P, Ryan JD, Tsochatzis EA: Fibrosis assessment in patients with chronic hepatitis B virus (HBV) infection. Ann Transl Med. 2017, 5:40. 10.21037/atm.2017.01.28

16. Itoh Y, Okanoue T, Ohnishi N, et al.: Serum levels of soluble tumor necrosis factor receptors and effects of interferon therapy in patients with chronic hepatitis C virus infection. Am J Gastroenterol. 1999, 94:13321340. 10.1016/S0002-9270(99)00139-2

17. García-Fernández M, Castilla-Cortázar I, Díaz-Sanchez M, et al.: Antioxidant effects of insulin-like growth factor-I (IGF-I) in rats with advanced liver cirrhosis. BMC Gastroenterol. 2005, 5:7. 10.1186/1471-230X-5-7

18. Arteh J, Narra S, Nair S: Prevalence of vitamin D deficiency in chronic liver disease . Digestive diseases and sciences. 2010, 55:2624-2628. 10.1007/s10620-009-1069-9

19. Guañabens N, Parés A, Alvarez L, et al.: Collagen-related markers of bone turnover reflect the severity of liver fibrosis in patients with primary biliary cirrhosis. J Bone Miner Res. 1998, 13:731-738.

20. Corazza GR, Trevisani F, Di Stefano M, et al.: Early increase of bone resorption in patients with liver cirrhosis secondary to viral hepatitis. Dig Dis Sci. 2000, 45:1392-1399. 10.1023/A:1005568406664

21. George J, Ganesh HK, Acharya S, et al.: Bone mineral density and disorders of mineral metabolism in chronic liver disease. World J Gastroenterol. 2009, 15:3516-3522. 10.3748/wig.15.3516

22. Goral V, Simsek M, Mete N: Hepatic osteodystrophy and liver cirrhosis. World J Gastroenterol. 2010, 16:1639-1643. 10.3748/wjg.v16.i13.1639

23. Naeem ST, Hussain R, Raheem A, Siddiqui I, Ghani F, Khan AH: Bone turnover markers for osteoporosis status assessment at baseline in postmenopausal Pakistani females. J Coll Physicians Surg Pak. 2016, 26:408-412. 